\title{
Derivation of toxicity equivalency factors for marine biotoxins associated with Bivalve Molluscs
}

\author{
Botana Luis M. ${ }^{1,{ }^{*}}$, Hess Philipp ${ }^{2}$, Munday Rex ${ }^{3}$, Nathalie Arnich ${ }^{4}$, Degrasse Stacey L. ${ }^{5}$, \\ Feeley Mark ${ }^{6}$, Suzuki Toshiyuki ${ }^{7}$, Van Den Berg Martin ${ }^{8}$, Fattori Vittorio ${ }^{9}$, Garrido Gamarro Esther ${ }^{10}$, \\ Tritscher Angelika ${ }^{11}$, Nakagawa Rei ${ }^{11}$, Karunasagar Iddya ${ }^{10}$
}

${ }^{1}$ Departamento de Farmacología, Facultad de Veterinaria, Universidad de Santiago, 27002 Lugo, Spain

${ }^{2}$ Institut Français de Recherche pour l'Exploitation de la Mer (IFREMER), Laboratoire Phycotoxines

(DYNECO/PHYC), Rue de I'lle d'Yeu, BP 21105, Nantes Cedex 3 44311, France

${ }^{3}$ AgResearch Ltd, Ruakura Research Centre, Private Bag 3123, Hamilton, New Zealand

${ }^{4}$ French Agency for Food, Environmental and Occupational Health \& Safety (ANSES), Risk

Assessment Department, Maisons-Alfort, France

${ }^{5}$ U.S. Food and Drug Administration, Center for Food Safety and Applied Nutrition, 5001 Campus Drive, College Park, MD 20740, USA

${ }^{6}$ Bureau of Chemical Safety, Food Directorate, Health Canada, Ottawa, ON, Canada

${ }^{7}$ National Research Institute of Fisheries Science, Fisheries Research Agency, 2-12-4 Fukuura,

Kanazawa, Yokohama, Kanagawa 236-8648, Japan

${ }^{8}$ Institute for Risk Assessment Sciences, University of Utrecht, Utrecht, The Netherlands

${ }^{9}$ Agriculture and Consumer Protection Department, Food and Agriculture Organization of the United Nations, Rome, Italy

${ }^{10}$ Fisheries and Aquaculture Department, Food and Agriculture Organization of the United Nations,

Rome, Italy

${ }^{11}$ Department of Food Safety and Zoonoses, World Health Organization, Geneva, Switzerland

* Corresponding author : Luis M. Botana, email address : luis.botana@usc.es

\begin{abstract}
:
Background

Seafood toxins pose an important risk to human health, and maximum levels were imposed by regulatory authorities throughout the world. Several toxin groups are known, each one with many analogues of the major toxin. Regulatory limits are set to ensure that commercially available seafood is not contaminated with unsafe levels.
\end{abstract}

Scope and Approach

The mouse bioassay was used to measure the toxicity in seafood extracts to determine if a sample exceeded regulatory limits. The advantage of this approach was to provide an estimation of the total toxicity in the sample. As instrumental methods of analysis advance and serve as replacements to the mouse bioassay, the challenge is translating individual toxin concentrations into toxicity to determine whether regulatory limits have been exceeded. Such analyses provide accurate quantitation of the toxin 
analogues, by they have widely dissimilar potencies. Thus, knowledge of the relative toxicities is required for risk assessment and determining overall toxicity. The ratios between the toxicity of the analogues and that of a reference compound within the same toxin group are termed "Toxicity Equivalency Factors" (TEFs).

Key Findings and Conclusions

In this document, the requirements for determining TEFs of toxin analogues are described, and recommendations for research to further refine TEFs are identified. The proposed TEFs herein, when applied to toxin analogue concentrations determined using analytical methods, will provide a base to determine overall toxicity, thereby protecting human health.

\section{Highlights}

- Marine toxins TEF are revised according to recent toxicology studies. TEF for each toxin group are proposed. The proposed TEF were agreed by a joint FAO-WHO working group.

Keywords : Marine toxins, Toxicity Equivalency Factors, FAO, WHO, Bivalve, Mollusc 
70

71

72

73

74

75

76

77

78

79

80

81

82

83

84

85

86

87

88

89

90

91

92

93

94

\section{Introduction}

Bivalve molluscs may be contaminated with marine biotoxins produced by microalgae and these toxins are an important cause of seafood intoxications, with symptoms that vary from mild diarrhoea to permanent neuropathy or death. Their presence is expanding worldwide, for reasons that are not fully understood, but appear to be linked to climate change, eutrophication and international trade (Hallegraef, 2015).

The limits for marine biotoxins for international trade are set by the CODEX Committee on Fish and Fishery Products (CCFFP), that has developed the Standard for Live and Raw Bivalve Molluscs (Codex, 2008). This Standard identifies maximum levels in mollusc flesh for 5 toxin groups, saxitoxin (STX), $<0.8 \mathrm{mg} / \mathrm{STX}$ equivalents (eq.) $/ \mathrm{kg}$, okadaic acid (OA), <0.16 mg/ OA eq. $/ \mathrm{kg}$, domoic acid (DA), $20 \mathrm{mg} / \mathrm{kg}$, brevetoxin (BTX), 200 mouse units/ or eq./kg, and azaspiracid (AZA), $0.16 \mathrm{mg} / \mathrm{kg}$. Each group of seafood toxins is comprised of many analogues of the major toxin, yet the regulatory levels are represented according to the total toxicity of the analogues. Traditionally regulatory limits were assessed using the mouse bioassay (MBA), which involves the intraperitoneal injection of seafood extracts (AOAC, 2005a; T. Yasumoto, Murata, Oshima, Matsumoto, \& Glardy, 1984; T. Yasumoto, Y. Oshima, \& M. Yamaguchi, 1978b). The advantage of the MBA is that it provides an estimate of the total toxicity of the sample. Instrumental analytical approaches are becoming available as alternatives to the MBA; such methods include liquid chromatography with ultraviolet, fluorescence or mass spectrometric detection (AOAC, 2005b; EU, 2011; These, Klemm, Nausch, \& Uhlig, 2011). These methods 
95 permit the quantitation of toxin analogues when compared to a certified

96 standard of the toxin (Antelo, Alfonso, \& Alvarez, 2014).

97 Quantitation of the toxin analogues is not, however, sufficient for monitoring and

98 regulatory decision making, since the different analogues may have widely

99 dissimilar toxic potencies. For such assessment, it is necessary to know the

100 relative toxicities of the components of the toxin mixture. These are termed

101 "Toxicity Equivalency Factors" (TEFs), which are defined as the toxicity ratio of a

102 compound from a chemical group that shares the same mode of action of a

103 reference compound in the same group. The toxicity of the analogue is expressed

104 as a fraction of the toxicity of the reference compound (Botana, et al., 2010; Van

105 den Berg, et al., 2006).

106 Accurate TEFs are essential for the monitoring and control of regulatory limits

107 set for groups of related compounds. The 34th Session of CODEX Committee on

108 Methods of Analysis and Sampling (CCMAS) encouraged CCFFP to investigate

109 TEFs for the marine biotoxins listed in the Standard. For this purpose, an Expert

110 Group was created by Food and Agricultural Organization (FAO) and World

111 Health Organization (WHO) to elaborate and propose a list of TEFs for each toxin

112 group for which limits are recommended in the Codex standards for Live and

113 Raw Bivalve Molluscs.

114 An additional toxin group, tetrodotoxin (TTX), was also considered given its

115 reported presence in shellfish (A. D. Turner, McNabb, Harwood, Selwood, \&

116 Boundy, 2015; Vlamis, et al., 2015). While TTXs are not specifically mentioned in

117 the CODEX standard, they have the same mode of action as STXs and can be 118 grouped along with the PSTs. 
120

121 The calculation of the amounts of different substances, sharing the same

122 mechanism of action, into the equivalent value for a single compound is a

123 complex process. It requires an understanding of both the mechanism of action

124 of the toxins, and how this mechanism translates into toxicity. In many cases,

125 such an understanding is not available, as with OA and its analogues, the

126 dinophysistoxins (DTXs). This toxin group, referred to as DSTs (diarrhetic

127 shellfish toxins) has been known for many years (T. Yasumoto, et al., 1978b).

128 Their toxicity has been suggested to result from inhibition of protein

129 phosphatases, particularly PP2A (Bialojan \& Takai, 1988), thereby disrupting

130 duodenal paracellular permeability due to alterations of tight junction integrity

131 (Tripuraneni, Koutsouris, Pestic, De Lanerolle, \& Hecht, 1997). However, recent

132 research results call into question both the target (Espina, et al., 2010; Wang, et

133 al., 2012) and the mechanism of toxicity of this group (Munday, 2013).

134 The Expert Group agreed on an approach for establishing TEFs which is 135 summarized in Figure 1. With respect to the relevance of toxicity data in the 136 derivation of TEFs the following order of priority was agreed:

137 1. Data from human intoxications, the most relevant data for the human 138 situation.

1392 , Acute toxicity data through oral administration to animals, relevant to the 140 route of human exposure.

141 3. Acute toxicity data through intraperitoneal (i.p.) administration to animals is 142 less valuable, since this is less relevant for the route of human exposure. It 143 should also be noted that there is no correlation between $\mathrm{LD}_{50}$ values obtained 144 by i.p. injection and those by oral administration. 
145 4. In vitro data. Such data are particularly useful when the mechanism of action

146 of the toxin is known, and the in vitro test system is relevant to this mechanism.

147 For those toxins with no clearly defined mode of action, with several known

148 targets, such as AZAs (Botana, et al., 2014) or with no reported lethal effect in

149 humans, such as DSTs (EFSA, 2008c), the data reported in the literature may be

150 confusing. While values for an $\mathrm{LD}_{50}$, a minimum lethal dose (MLD) or the non-

151 specific term "lethality" have been reported (Munday, 2014). It is of little use to

152 define a TEF for humans based on the dose of AZA that kills a mouse. Therefore,

153 the toxic potency of AZAs in humans is somewhat biased by reference to effects

154 in rodents, although there is presently no other way to quantify them. Another

155 important bias is the lack of information on the chronic effect of toxins that cause

156 death after repeated sub-lethal doses (Ferreiro, et al., 2016b), and which may

157 also be toxic through the long-term ingestion of non-lethal amounts, such as

158 described for DA (Truelove, Mueller, Pulido, \& Iverson, 1996; Vieira, et al., 2015).

159 The approach applied by the Expert Group to establish TEFs is summarized in

160 Figure 1. Table 1 lists the uncertainties associated to TEF definitions for each

161 toxin group.

162

163 Saxitoxin group

164

165 This group of toxin analogues has saxitoxin (STX) as the reference compound, 166 and they share a common structure of tetrahydropurine. These toxins are mainly 167 produced by dinoflagellates of the genus Alexandrium, but Pyrodinium and 168 Gymnodinium are also potential sources (Wiese, D'Agostino, Mihali, Moffitt, \& 169 Neilan, 2010). More than 50 compounds have been reported (Wiese, et al., 2010) 
and at least 18 have been demonstrated to have toxicological relevance. They are soluble in water and thermostable at acidic $\mathrm{pH}$; at alkaline $\mathrm{pH}$ they are quickly degraded (Kodama \& Sato, 2008).

STX and analogues exert their toxic effects in animals by binding to the voltagegated sodium channel $\left(\mathrm{Na}_{\mathrm{v}}\right)$ (Payandeh, Scheuer, Zheng, \& Catterall, 2011). This channel contains one alpha subunit and one to three small beta subunits. There are 9 alpha subunits of the $\mathrm{Na}_{\mathrm{v}}$ channel $\left(\mathrm{Na}_{\mathrm{v}} 1\right.$ to 9$)$ (Wingerd, Vetter, \& Lewis, 2012), and originally they were divided into tetrodotoxin (TTX)-sensitive $\left(\mathrm{Na}_{\mathrm{v}} 1\right.$, 2, 3 and 7) and TTX insensitive. The alpha subunits contain 4 homologous domains, each with 6 hydrophobic transmembrane segments. There are 6 binding sites that are the targets for many toxins, including several phycotoxin groups. Site 1 is the receptor for TTX and STXs and site 5 is the receptor for ciguatoxins (CTXs) and BTXs (Hartshorne \& Catterall, 1981). The major molecular mechanism of toxicity of both TTX and STX is to block the channel pore, thereby inhibiting the conductance of the channel and the transmission of electrical action potentials generated by the influx of sodium ions into the cell. This mechanism is responsible for muscle paralysis, potentially leading to paralysis of the diaphragm and death.

Sommer and Mayer reported a quantitative MBA for STX (Sommer \& Meyer, 1937), which is based on the dose-death time relationship in mice dosed intraperitoneally with this toxin. This MBA, which is now an approved AOAC method (Hungerford, 1995), has been widely used for comparing the toxicity of STX analogues (Oshima, 1995). The assumption is that the dose-death time relationship is the same for all analogues, yet that is not case, (Munday, Thomas, 
194 Gibbs, Murphy, \& Quilliam, 2013), which calls into question the validity of this 195 assay for the calculation of TEFs.

196 Table 2 shows the relative potencies determined by MBA as presented in the 197 scientific literature. There is a correlation between the relative specific activity 198 and relative toxicity by ip. injection with some STX derivatives; however, with 199 NeoSTX, GTX $1 \& 4$ and dcGTX 2\&3, there is no such correlation. This is 200 attributable to differences in the dose-death time relationship (Munday, et al., 201 2013). The differences among the values shown in Table 2 in many cases most 202 likely reflect the use of impure compounds, although the estimates for NeoSTX 203 reported (Munday, et al., 2013) and (Vale, Alfonso, et al., 2008), using certified 204 toxins, are significantly different. As certified STX analogues became available, a 205 list of relative potency was proposed by the European Food Safety Authrority 206 (EFSA) based on the effect of certified toxins on neuronal cultures and on MBA 207 (EFSA, 2009). These values were reevaluated using oral administration (gavage 208 or feeding) (Munday, et al., 2013). In some cases, the results were similar to 209 those obtained through i.p. administration, but differences were observed for 210 other congeners. The TEF for dcSTX was 0.64 in the MBA and 0.785 by the i.p. 211 route compared to 0.37 by feeding and 0.46 by gavage. The TEF for dcNeoSTX 212 was 0.4 in the MBA and 0.058 by i.p. injection compared to 0.22 by both gavage 213 and feeding. Importantly, the TEF for the oral toxicity of NeoSTX was higher (1.7 214 by gavage, 2.5 by feeding) compared to 1.16 by i.p. injection. The TEF for the oral 215 toxicity of NeoSTX was (1.7 by gavage, 2.5 by feeding) compared to 1.16 in the 216 MBA and 3.12 by i.p. injection.

217 There are in vitro methods that compare the effects of STX with its congeners, as 218 shown in Table 3. The EFSA TEFs for GTX-1\&4, GTX-2\&3 and C1,2 are consistent 
219 with those determined by oral administration. In contrast, the TEF for NeoSTX

220 was significantly higher than that proposed by EFSA, while the proposed TEFs

221 for GTX5, GTX6, dcSTX, dcNeoSTX were lower. There are two toxins that require

222 further clarification: dcSTX was recently reported by some authors to be less

223 toxic than STX, with TEF of 0.8 (Vale, Alfonso, et al., 2008), 0.64 (Munday, et al.,

224 2013), 0.478 (Suzuki \& Machii, 2014) and 0.37 (Suzuki \& Machii, 2014), and

225 NeoSTX from 1 (Alonso, Alfonso, Vieytes, \& Botana, 2016; EFSA, 2009) to 2.54

226 (Munday, et al., 2013). It is interesting to note that there is a better match

227 between the results obtained with $\mathrm{Na}_{\mathrm{v}}$ subtype 1.2 channel blockage (Alonso, et

228 al., 2016) and with oral administration to mice (Munday, et al., 2013).

\section{Okadaic acid group}

232 This group of toxins has $\mathrm{OA}$ as the reference compound. OA was originally

233 isolated from the sponge Halichondria okadaii (Tachibana, et al., 1981) and

234 linked to diarrhetic shellfish poisoning (DSP) (T. Yasumoto, Y. Oshima, \& M.

235 Yamaguchi, 1978a) through dinophysistoxin-1 (DTX1), produced by Dinophysis

236 fortii. Dinophysistoxin-2 (DTX2) was discovered as a third main analogue (Hu, et

237 al., 1992) in Irish mussels associated with diarrhetic episodes. OA and DTXs are 238 produced by Dinophysis and Prorocentrum species.

239 OA is a polyether characterised by a carboxylic acid group and three spiro-keto 240 ring assemblies, one of which connects a five with a six-membered ring. OA, 241 DTX1 and DTX2 withstand a wide $\mathrm{pH}$ and temperature range in methanolic $242 \mathrm{NaOH}$ solution. Strong mineral acids cause their rapid degradation in $20 \mathrm{~min}$ at $24376{ }^{\circ} \mathrm{C}$ even with shellfish matrix in the extract (T. Yasumoto, Murata, Oshima, \& 
244 Sano, 1985), but food itself can buffer the acid and the toxins may be stable in the

245 stomach after a meal (Alfonso, et al., 2008).

246 There are different types of esters of OA and DTXs. They are all fatty acid esters

247 (palmitic being the most common) of OA, DTX1 and DTX2, of variable chain

248 length and referred to as DTX3. The multitude of compounds potentially present

249 in shellfish (free toxins, diol esters and their derivatives, fatty acids and mixtures

250 of diol- and fatty acid esters) complicates the determination of overall toxic

251 potential of shellfish samples. All of the esters are quantitatively cleaved through

252 treatment with strong base, e.g. 0.3 molar methanolic $\mathrm{NaOH}$ at $76^{\circ} \mathrm{C}$ for 10 to 40

253 min (Marr, Hu, Pleasance, Quilliam, \& Wright, 1992).

254 The target of $\mathrm{OA}$ and analogues is suggested to be protein phosphatases (PP), 255 especially PP2A (ID 50 1,2 nM) and, as secondary targets, PP1 (ID $50315 \mathrm{nM}$ ) and 256 PP2B (ID 504530 nM)(Bialojan \& Takai, 1988; Takai, Bialojan, Troschka, \& Ruegg, 257 1987). Table 4 shows the intraperitoneal (i.p.) and in vitro (i.v.) toxicities of this 258 group of compounds. There is remarkable consistency among the cell lines 259 tested, with DTX-1 showing a 2-4 fold higher activity than OA, and DTX-2 260 showing less toxicity than OA, by a factor of between 0.35 and 0.73 .

261 DTX-1 shows similar toxicity in mice when administered either 262 intraperitoneally or by oral administration, with fluid accumulation in the 263 gastrointestinal tract of mice dosed with DTX1 at 0.4 and $0.32 \mu \mathrm{g} / \mathrm{mouse}$ for OA 264 and DTX1, respectively (Tubaro, Sosa, Bornacin, \& Jungerford, 2008). The lethal 265 dose of DTX1 by oral administration has been reported as below $300 \mu \mathrm{g} / \mathrm{kg}$ b.w. 266 (all animals dead) in fasted animals (Munday, 2014; Ogino, Kumagai, \& 267 Yasumoto, 1997), while other studies reported no deaths in mice or rats given 268 DTX-1 orally at $750 \mathrm{mg} / \mathrm{kg}$ b.w. (Ito \& Terao, 1994; Terao, Ito, Ohkusu, \& 
269 Yasumoto, 1993). No published reports regarding the oral toxicity of DTX2 are

270 available, although a work not yet published (Louzao, pers comm.) has concluded

271 that the oral $\mathrm{LD}_{50}$ is $2,150 \mu \mathrm{g} / \mathrm{kg}$ b.w. (death at $24 \mathrm{~h}$, mice fasted for $12 \mathrm{~h}$,

272 administration by gavage) and that the $\mathrm{LD}_{100}$ is $3,000 \mu \mathrm{g} / \mathrm{kg}$ b.w., all animals

273 dying in less than $5 \mathrm{~h}$. No damage to the GI tract mucosa was observed in this

274 study. Although the toxicity of DTX-1 by gavage appears to be higher than that of

275 OA, the variability among published values precludes an estimate of TEFs based

276 on oral toxicity. A recent study on the cardiotoxic effects of OA (20 $\mu \mathrm{g} / \mathrm{kg}$ b.w.)

277 and DTX1 (16 $\mu \mathrm{g} / \mathrm{kg})$ in rats showed no cardiotoxic effects of these compounds

278 in acute experiments as assessed either by the electrocardiogram or by

279 biomarkers (Ferreiro, et al., 2015). The TEFs recommended by the Expert group

280 for OA group are indicated in Table 6.

281

282 Azaspiracid group

283

284 This group of toxins has AZA1 as the reference compound. The first intoxication by

285 AZAs was recognised in 1996 (McMahon, 1996). These compounds are produced

286 by the genera Azadinium and Amphidoma (Krock, et al., 2012; Tillmann, Salas,

287 Jauffrais, Hess, \& Silke, 2014). Their structure is unusual in that they have a

288 unique spiro ring assembly and a cyclic amine instead of a cyclic imine group; a

289 carbocyclic or lactone ring is absent (Satake, Ofuji, Naoki, et al., 1998); their

290 mechanism of toxicity is presently unknown (Botana, et al., 2014). Long term

291 effects are inconclusive (EFSA, 2008b; Ito, et al., 2002), although damage to

292 multiple organs was reported following oral administration to mice, with injury 
293 to the intestinal epithelium, lamina propria and villi, and a lethal oral dose of 700

$294 \mu \mathrm{g} / \mathrm{Kg}$ b.w. (Ito, et al., 2002).

295 AZAs are readily absorbed after oral administration to mice (Aune, et al., 2012).

296 They were first detected 30 minutes after administration to pigs, with peak 297 levels achieved after $4 \mathrm{~h}$ (Twiner, Hess, \& Doucette, 2014). In humans, they cause 298 vomiting, nausea, diarrhoea and stomach cramps within a few hours after 299 ingestion (Klontz, Abraham, Plakas, \& Dickey, 2009). No deaths from AZA 300 ingestion have been reported. The EFSA working group established an acute 301 reference dose (ARfD) of $0.2 \mu$ g AZA equivalents/kg body weight (b.w.) (EFSA, 302 2008b). The Joint FAO/IOC/WHO ad hoc Expert Consultation established a 303 provisional ARfD of $0.04 \mu \mathrm{g} / \mathrm{kg}$ b.w. body weight but were unable to establish a 304 Tolerable Daily Intake (A. CODEX, 2006).

305 AZAs target several apoptotic modulators (Botana, et al., 2014; Roman, et al., 306 2002; Twiner, et al., 2005), such as caspase, cytoskeleton (Vilarino, Nicolaou, 307 Frederick, Vieytes, \& Botana, 2007), cytochrome release (Twiner, Hanagriff, 308 Butler, Madhkoor, \& Doucette, 2012), c-jun-N-terminal protein kinase (JNK), 309 calcium levels (Cao, LePage, Frederick, Nicolaou, \& Murray, 2010; Vale, 310 Wandscheer, et al., 2008), fatty acid biosynthesis (Twiner, et al., 2008). AZAs 311 decrease cell volume mediated by potassium and chloride efflux (Vale, Nicolaou, 312 Frederick, Vieytes, \& Botana, 2010), deplete ATP (Kellmann, et al., 2009), inhibit 313 endocytosis (Bellocci, Sala, Callegari, \& Rossini, 2010) and decrease procathepsin 314 pools in endocytosis (Sala, Bellocci, Callegari, \& Rossini, 2013). The observation 315 that AZAs are present only in mussel samples with high levels of glutaric acid is 316 intriguing, and a combination of AZA and glutaric acid blocks voltage-dependent 
317 sodium channels (Chevallier, et al., 2015), which could explain the neurotoxicity

318 linked to AZA (Twiner, et al., 2014).

319 AZAs block open hERG potassium channels (Twiner, Doucette, et al., 2012), and

320 this translates into the in vivo acute $(11 \mu \mathrm{g} / \mathrm{kg}$ ) and subacute (four doses of 10

$321 \mu \mathrm{g} / \mathrm{Kg}$ in 15 days) cardiotoxicity of AZAs through hERG channels in rats

322 (Ferreiro, et al., 2016b; Ferreiro, et al., 2014). Ultrastructural changes in the

323 hearts of rats were observed at a dose of $1 \mu \mathrm{g} / \mathrm{kg}$ b.w. i.p. The possible

324 cardiotoxic effect of this group requires further investigation.

325 Acute toxicity data on AZAs are shown in Table 5. The TEFs recommended by the 326 Expert group for AZAs are indicated in Table 6.

Domoic acid

330 Domoic acid is a globally distributed excitotoxin produced by the red macroalga

331 Chondria armata (Takemoto \& Daigo, 1958), and by diatoms of the genera 332 Nitzschia, Pseudo-nitzschia (Bates, et al., 1989) and Amphora (Dhar, et al., 2015).

333 The worldwide distribution of the toxin producing organisms makes the 334 presence of DA rather ubiquitous in the world oceans. A TEF of one is applicable, 335 as only DA and its diastereoisomer, epi-DA, have been shown to be of 336 toxicological relevance (sum of DA and epi-DA expressed as DA).

\section{Brevetoxins}

339 Brevetoxins target the neurotoxin receptor site five voltage gated sodium

340 channels, resulting in membrane depolarization, prolongation of open time, 341 prevention of channel inactivation, induction of the channel activation at more 
342 negative potentials, thereby causing repetitive firing and increases in sodium

343 currents (Atchison, Luke, Narahashi, \& Vogel, 1986; Trainer, Moreau, Guedin,

344 Baden, \& Catterall, 1993). These effects lead to rapid reductions in respiratory

345 rate, cardiac rhythm alterations, and hypothermia (Templeton, Poli, \& LeClaire, 346 1989).

347 Brevetoxins have a polyether backbone and can be grouped into two types. 348 BTX1 (also referred to in the literature as PbTx1) represents the A-type toxins 349 and has been reported to be the most toxic of the BTX analogues (Shimizu, Chou, 350 Bando, Van Duyne, \& Clardy, 1986). BTX2 (also referred to as PbTx2), 351 representing the B-type toxins, is the most abundantly produced by the source 352 dinoflagellate Karenia brevis (Shimizu, et al., 1986). Following a neurotoxic 353 shellfish poisoning outbreak in New Zealand in 1992-1993, it was found that 354 BTXs are extensively metabolized in shellfish (Ishida, et al., 1995). Of the 355 metabolites identified in shellfish from New Zealand BTX-B1 was found to be 356 most toxic (Ishida, et al., 1995). BTX-B4 was threefold more toxic than BTX-B2 357 and comparable to the toxicity of BTX3 (also referred to as PbTx3) (Baden \& 358 Mende, 1982; Morohashi, et al., 1999; Poli, Mende, \& Baden, 1986). There is 359 limited human oral data available for establishing TEFs; currently, the CODEX 360 Standard method for BTXs is the MBA and the regulatory limit is expressed as 361 mouse units. For this reason, TEFs for BTXs are not currently proposed.

364 The special case of tetrodotoxin and emerging toxins

365 TTX is a marine toxin of bacterial origin and is produced, amongst others, by 366 Pseudomonas and Vibrio spp. (Bane, Lehane, Dikshit, O'Riordan, \& Furey, 2014). 
367 It is becoming a concern in Europe given its presence in gastropods (Rodriguez,

368 et al., 2008; Silva, et al., 2012) and in shellfish (A. Turner, Powell, Schofield, Lees,

369 \& Baker-Austin, 2015; Vlamis, et al., 2015). Because TTX in shellfish is a newly-

370 discovered phenomenon, there is presently no surveillance programme for TTX

371 in place. The mode of action is similar to that of STX, with main difference

372 between the toxin groups being the subtypes of $\mathrm{Na}_{\mathrm{v}}$ for which they preferentially

373 bind. In the case of TTX, the $\mathrm{Na}_{\mathrm{v}} 1.7$ is the main target (Alonso, et al., 2016;

374 Walker, et al., 2012), although TTX can bind with lower affinity to other $\mathrm{Na}_{\mathrm{v}}$

375 subtypes. TTX binds to human $\mathrm{Na}_{\mathrm{v}} 1.7$ with 38 fold more potency than STX

376 (Walker, et al., 2012).

377 The human lethal dose of TTX is $2 \mathrm{mg}$ (Noguchi, Onuki, \& Arakawa, 2011). Based

378 on the intraperitoneal toxicity to mice, relative toxicities of TTX analogues have

379 been reported in the literature (Bane, et al., 2014).

380 The lethality of TTX decreases with the route of administration, from $10 \mu \mathrm{g} / \mathrm{kg}$

381 b.w. i.p., to $16 \mu \mathrm{g} / \mathrm{kg}$ b.w. subcutaneous, and $332 \mu \mathrm{g} / \mathrm{kg}$ b.w. oral (Kao, 1966; E. G.

382 Moczydlowski, 2013).

383 The Expert Group suggested an emerging need to establish TEFs for TTX 384 analogues that may be found in bivalves, indicating a requirement for oral 385 toxicity data on the analogues.

386 It was also suggested that other emerging toxins, such as palytoxin, ovatoxins, 387 ostreocins and cyclic imines should be further investigated to determine the 388 actual risk to consumers (Munday, 2014). 
392 The work reported in this paper is the output of a Joint FAO/WHO Expert 393 Meeting on "Toxicity Equivalency Factors for marine biotoxins associated with 394 bivalve molluscs" held in Rome on February 22-24, 2016. The full report of the 395 meeting will be available on FAO/WHO websites.

396 
Table 1. Uncertainties in the definition of TEFs, from high (+++) to low (-) or no relevance if complete information is not available.

\begin{tabular}{|c|c|c|c|c|}
\hline Toxin group & $\begin{array}{c}\text { Mode of action (to } \\
\text { explain toxicity) }\end{array}$ & $\begin{array}{c}\text { Animal data relevant to } \\
\text { human effect }\end{array}$ & $\begin{array}{c}\text { Known potency of } \\
\text { each analogue }\end{array}$ & $\begin{array}{c}\text { Chronic toxicity } \\
\text { information } \\
\text { available }\end{array}$ \\
\hline STX ${ }^{*}$ & - & - & ++ & ++ \\
\hline OA ** & ++ & ++ & - & ++ \\
\hline DA \# & - & + & + & + \\
\hline BTX @ & + & + & + & ++ \\
\hline AZA \& & +++ & ++ & + & + \\
\hline
\end{tabular}

* Most of the required information is available for common toxins, but new toxins, such as benzoate derivatives, and dcSTX or NeoSTX require further research about their potency. Benzoate derivatives toxicity and an enhanced understanding of the pharmacokinetics of the group are also needed. 
** Analogues that lack phosphatase inhibition have potent cellular effects (Espina, et al., 2010), therefore the mechanism for diarrhoea needs to be understood (Louzao, et al., 2015; Munday, 2013). Other phosphatase inhibitors do not show a diarrhetic effect. This suggests other factors are involved in the mechanism of toxicity, i.e. neuropeptide Y inhibition (Louzao, et al., 2015). No damage to the mucosa was observed while severe diarrhoea was induced (Vieira, et al., 2013). Oral studies with the same methodology are also required.

\# Target is well known (Hogberg \& Bal-Price, 2011), but long term effects are unclear with regard to endocrine (Crespo, et al., 2015), cardiotoxic (Vieira, et al., 2016; Vranyac-Tramoundanas, Harrison, Sawant, Kerr, \& Sammut, 2011), or prenatal toxicity (Levin, Pizarro, Pang, Harrison, \& Ramsdell, 2005).

@ Several aspects of toxicity needs further investigation, such as effects on smooth muscle mediated by the autonomic nervous system, cardiotoxicity, or body temperature (Abraham, et al., 2005; Berman \& Murray, 2000; Gordon, Kimm-Brinson, Padnos, \& Ramsdell, 2001). \& Several target candidates, but no identified mode of action (Botana, et al., 2014; Twiner, Doucette, et al., 2012; Vilarino, et al., 2007). Many compounds without mechanistic studies (Marine-Institute, 2014). Unclear long term toxicity (EFSA, 2008a; Ferreiro, et al., 2016b). 
Table 2. Relative toxicity of STX derivatives as indicated by the MBA.

\begin{tabular}{|l|l|l|}
\hline Compound & Relative specific activity in the MBA & Relative LD 50 by \\
& & i.p. injection ${ }^{1}$ \\
\hline Saxitoxin & 1.0 & 1.00 \\
\hline NeoSTX & $0.50,0.75^{2}, 0.90,0.90,1.0,1.16^{1}, 1.2$ & 3.12 \\
\hline GTX-1 & $0.80,1.0$ & \\
\hline GTX-4 & $0.30,0.70$ & \\
\hline GTX-1\&4 & $0.70,1.02^{1}, 0.65^{2}$ & 1.90 \\
\hline GTX-2 & $0.40,0.40$ & \\
\hline GTX-3 & $0.60,1.1$ & \\
\hline GTX-2\&3 & $0.60,0.60^{1}, 0.52^{2}$ & \\
\hline GTX-5 & $0.10,0.10,0.20,0.1^{5}$ & \\
\hline GTX-6 & $0.10,<0.1^{5}$ & 0.122 \\
\hline C-1 & $0.02,0.00$ & \\
\hline C-2 & $0.10,0.17$ & \\
\hline C-3 & $0.40,0.48^{3}, 0.50,0.50,0.60,0.641$ \\
\hline C-4 & & 0.785 \\
\hline dcSTX & & \\
\hline & & \\
\hline
\end{tabular}




\begin{tabular}{|c|c|c|}
\hline & $1.0,1.02^{2}$ & \\
\hline dcNeoSTX & $0.40,0.020^{4}$ & 0.058 \\
\hline dc-GTX-1 & 0.5 & \\
\hline dc-GTX-2 & $0.20,0.20,0.30$ & \\
\hline dc-GTX-3 & $0.20,0.40,0.50$ & \\
\hline dc-GTX-4 & 0.50 & \\
\hline dc-GTX-2\&3 & $0.20,0.19^{2}$ & 0.695 \\
\hline 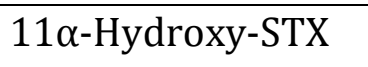 & 0.60 & \\
\hline 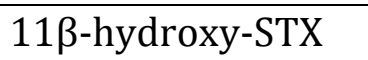 & 0.70 & \\
\hline TTX $^{5}$ & & $\begin{array}{l}1.1 \text { (compared to } \\
\text { STX) }\end{array}$ \\
\hline 11-deoxy-TTX & & 7.7 \\
\hline 6,11-dideoxy TTX & & 46 \\
\hline 11-охо-TTX & & 1.7 \\
\hline 4-epi-TTX & & 7 \\
\hline 6-epi-TTX & 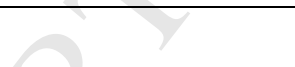 & 6.6 \\
\hline 4,9-Anhydro-TTX & & 53.6 \\
\hline 11-nor-TTX-6(S)-ol & & 5.9 \\
\hline 11-nor-TTX-6(R)-ol & & 7.6 \\
\hline
\end{tabular}

Data are taken from Table 13 of the 2009 ESFA report on saxitoxin group toxins (EFSA, 2009) and modified as indicated by superscript numerals.

1. (Munday, et al., 2013). 2. (Vale, Alfonso, et al., 2008). 3. (Suzuki \& Machii, 2014). 4. Munday, unpublished results. 5 (Watanabe, Suzuki, \& Oshima, 2010). A mouse unit for STX is $0.183 \mu \mathrm{g}(9.15 \mu \mathrm{g} / \mathrm{kg}$ b.w.) (AOAC, 2005a; Schantz, 
McFarren, Schafer, \& Lewis, 1958), and the potency of STX is 10 percent higher than TTX. 5. A basic TEF list for TTX, compared to STX (T. Yasumoto, YotsuYamashita, Murata, \& Naoki, 1988). Further information is needed for each TTX derivative. 
Table 3. Relative toxicities of STX and derivatives in mice through oral administration (gavage/voluntary feeding) and relative activities toward sodium channels in vitro.

\begin{tabular}{|c|c|c|c|c|c|c|c|c|c|c|}
\hline \multirow[t]{2}{*}{ Compound } & \multirow{2}{*}{$\begin{array}{l}\text { Relative toxicity by } \\
\text { voluntary feeding/ } \\
\text { gavage * }\end{array}$} & \multicolumn{9}{|c|}{ Relative activity toward sodium channels in vitro by type of assay method ${ }^{1}$} \\
\hline & & $\begin{array}{l}1 \\
\text { squid } \\
\text { axon }\end{array}$ & $\begin{array}{l}2 \\
\text { rat } \\
\text { cortex }\end{array}$ & $\begin{array}{l}3 \\
\text { frog } \\
\text { sciatic } \\
\text { nerve }\end{array}$ & $\begin{array}{l}4 \\
\text { frog } \\
\text { muscle } \\
\text { fibre }\end{array}$ & $\begin{array}{l}5 \\
\text { rat } \\
\text { muscle }\end{array}$ & $\begin{array}{l}6 \\
\text { cultured } \\
\text { neurons }\end{array}$ & $\begin{array}{l}7 \\
\text { cerebellar } \\
\text { neurons }\end{array}$ & $\begin{array}{l}8, \\
\mathrm{Na}_{\mathrm{v}} 1,6\end{array}$ & $\begin{array}{l}8, \\
\mathrm{Na}_{\mathrm{v}} 1,2\end{array}$ \\
\hline STX & 1.00 & 1.0 & 1.0 & 1.0 & 1.0 & 1.0 & 1.0 & 1.0 & 1.0 & 1.0 \\
\hline neoSTX & $2.54 / 1.7$ & - & 0.69 & 4.5 & 1.0 & $3.6 / 3.7$ & 0.82 & 1.02 & 1.2 & 2.0 \\
\hline GTX 1 & & - & - & - & - & 0.28 & - & - & & \\
\hline GTX $1 \& 4$ & $0.936 / 0.739$ & - & 0.98 & - & - & - & 0.53 & 0.50 & 1.4 & 0.54 \\
\hline GTX 2 & & 0.2 & & 0.22 & & $\begin{array}{l}0.15 / \\
0.16\end{array}$ & & & & \\
\hline
\end{tabular}




\begin{tabular}{|c|c|c|c|c|c|c|c|c|c|c|}
\hline GTX 2\&3 & $0.572 / 0.533$ & - & 0.32 & - & - & - & 0.38 & 0.28 & 0.15 & 0.4 \\
\hline GTX 3 & & 0.42 & - & 1.4 & - & 0.96 & & & & \\
\hline GTX 4 & & - & - & - & - & & & & & \\
\hline GTX 5 & $0.064 / 0.05$ & - & 0.031 & - & - & 0.024 & 0.09 & 0.09 & 0.11 & 0.01 \\
\hline GTX 6 & $<0.017 / 0.038$ & - & - & - & - & $-\quad 0$ & & & & \\
\hline dcSTX & $0.368 / 0.457$ & - & 0.097 & - & 0.2 & 0.44 & 0.84 & 1.00 & 0.96 & 0.25 \\
\hline dcNeoSTX & $0.224 / 0.216$ & - & - & - & 0.004 & - & 0.48 & 0.44 & 0.25 & 0.1 \\
\hline dcGTX2,3 & $0.108 / 0.167$ & & & 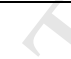 & & & & & 0.02 & 0.05 \\
\hline C1 & - & - & - & - & - & $\begin{array}{l}0.0017 / \\
0.0028\end{array}$ & & & & \\
\hline $\mathrm{C} 2$ & & - & - & - & - & 0.029 & & & & \\
\hline $\mathrm{C} 1,2$ & $0.043 / 0.034$ & & & & & & & & 0.09 & 0.01 \\
\hline
\end{tabular}




\begin{tabular}{|l|l|l|l|l|l|l|l|l|l|}
\hline C3 & - & - & - & - & - & 0.002 & & \\
\hline
\end{tabular}

Note 1 - Assay methods:

* Relative toxicity by voluntary feeding/ gavage (Munday, et al., 2013).

1: Relative blockade of sodium channels in the squid giant axon (Kao, et al., 1985).

2: Relative binding to sodium receptors of the rat cerebral cortex (Llewellyn, 2006; Usup, Leaw, Cheah, Ahmad, \& Ng, 2004).

3: Relative blockade of impulses in frog sciatic nerve (Strichartz, 1984).

4: Relative blockade of sodium current in frog skeletal muscle fibre (Kao \& Walker, 1982; Yang, Kao, \& Oshima, 1992).

5: Relative blockade of sodium channels from rat muscle plasma membrane (Guo, et al., 1987; E. Moczydlowski, Hall, Garber, Strichartz, \& Miller, 1984).

6: Blockade of veratridine-induced changes in membrane potential in cultured neurons (Vale, Alfonso, et al., 2008).

7: Sodium currents voltage-dependent inhibition in primary cultures of cerebellar neurons (Perez, et al., 2011).

8. High-throughput electrophysiology system, in cells stably transfected with specific subunits of sodium channels (Alonso, et al., 2016). 
Table 4. Toxicities of OA and its analogues by i.p. injection (Munday, 2014). Large discrepancies are most likely due to the use of non-certified calibrants.

\begin{tabular}{|c|c|c|}
\hline Compound & Parameter & Acute toxicity ( $\mu \mathrm{g} / \mathrm{kg}$ b.w.) \\
\hline $\mathrm{OA}$ & $\mathrm{LD}_{50}$ & 192 (Tachibana, et al., 1981) \\
\hline $\mathrm{OA}$ & $\mathrm{LD}_{50}$ & 200 (pers. comm. T. Yasumoto, 1991) \\
\hline $\mathrm{OA}$ & No death & 200 (Ito \& Terao, 1994) \\
\hline $\mathrm{OA}$ & $\mathrm{LD}_{50}$ & 204 (Aune, et al., 2012) \\
\hline $\mathrm{OA}$ & $\mathrm{LD}_{50}$ & $\begin{array}{l}210 \text { (Dickey, Bobzin, Faulkner, Bencsath, \& } \\
\text { Andrzejewski, 1990) }\end{array}$ \\
\hline $\mathrm{OA}$ & $\mathrm{LD}_{50}$ & 225 (Tubaro, et al., 2003) \\
\hline $\mathrm{OA}$ & $\mathrm{LD}_{40}$ to $\mathrm{LD}_{100}$ & mean 227, range 216-242, (Suzuki, 2012) \\
\hline $\mathrm{OA}$ & $\mathrm{LD}_{100}$ & 375 (Ito \& Terao, 1994) \\
\hline DTX1 & MLD & $\begin{array}{l}160 \text { (Murata, Shimatani, Sugitani, Oshima, \& } \\
\text { Yasumoto, 1982; T Yasumoto \& Murata, } \\
\text { 1990) }\end{array}$ \\
\hline DTX1 & $\mathrm{LD}_{50}$ & $\begin{array}{l}160 \text { (pers. comm. T. Yasumoto, } \\
\text { 1991)(Dominguez, et al., 2010) }\end{array}$ \\
\hline DTX1 & $\mathrm{LD}_{100}$ & 375 (Ito \& Terao, 1994) \\
\hline DTX2 & $\mathrm{LD}_{50}$ & 352 (Aune, et al., 2007) \\
\hline DTX3 & $\mathrm{LD}_{100}$ & 375 (Ito \& Terao, 1994) \\
\hline DTX3 & MLD & 500 (T. Yasumoto, et al., 1985) \\
\hline
\end{tabular}




\begin{tabular}{|l|l|l|}
\hline DTX4 & LD $_{50}$ & $610(\mathrm{Hu}$, Curtis, Walter, \& Wright, 1995) \\
\hline
\end{tabular}

\section{In vitro cell toxicities of $\mathrm{OA}, \mathrm{DTX}-1$ and $\mathrm{DTX}-2$}

\begin{tabular}{|l|l|l|l|l|l|l|}
\hline Compound & \multicolumn{5}{l}{ Relative toxicity in the specified cell line } \\
& SH-SY5Y & Neuro- & NG108- & MCF-7 & Caco-2 & HT29- \\
& (Louzao, & 2a & 15 & (Solino, & (Ferron, & MTX \\
& et al., & (Solino, & (Solino, et & et al., & Hogeveen, & (Ferron, \\
& 2015) & Sureda, & al., 2015) & 2015) & Fessard, & et al., \\
& & $\&$ & Diogene, & & \&e $)$ & 2014 ) \\
& & $2015)$ & & Hegarat, & \\
\hline OA & 1.0 & 1.0 & 1.0 & 1.0 & 1.0 & 1.0 \\
\hline DTX1 & 4.4 & 2.1 & 2.4 & 3.8 & 2.2 & 3.4 \\
\hline DTX2 & & 0.52 & 0.52 & 0.73 & 0.47 & 0.35 \\
\hline
\end{tabular}

Table 5. Toxicities of AZAs

\section{Intraperitoneal injection}

\begin{tabular}{|l|l|l|}
\hline Compound & Parameter & Acute toxicity $(\mu \mathrm{g} / \mathrm{kg}$ b.w. b.w) (reference) \\
\hline AZA1 & Lethality & 200 (Munday, 2014) \\
\hline AZA1 & MLD & 150 (Satake, Ofuji, James, Furey, \& Yasumoto, 1998) \\
\hline AZA1 & LD $_{50}$ & 74 (Marine-Institute, 2014) \\
\hline AZA1 & LD 50 & $>10$ and $<55$ in rats (Ferreiro, et al., 2016a) \\
\hline AZA2 & Lethality & Approximately 110 (Munday, 2014) \\
\hline AZA2 & LD50 & 117 (Marine-Institute, 2014) \\
\hline
\end{tabular}




\begin{tabular}{|l|l|l|}
\hline AZA2 & LD50 (i.v.) & 11 in rats (Ferreiro, et al., 2014) \\
\hline AZA3 & Lethality & Approximately 140 (Munday, 2014) \\
\hline AZA3 & LD50 & 164 (Marine-Institute, 2014) \\
\hline AZA4 & Lethality & Approximately 470 (Munday, 2014) \\
\hline AZA5 & Lethality & $<1000$ (Munday, 2014) \\
\hline AZA6 & LD50 & 100 (Marine-Institute, 2014) \\
\hline
\end{tabular}

\section{Oral administration}

\begin{tabular}{|l|l|l|l|}
\hline Compound & Parameter & Acute & Reference \\
& & toxicity & \\
& & b.w.) & \\
& & $>700$ & (Ito, 2008) \\
\hline AZA1 & Lethality & 775 & (Aune, et al., 2012) \\
\hline AZA1 & LD 50 & 443 & (Marine-Institute, 2014) \\
\hline AZA1 & LD 50 & 626 & (Marine-Institute, 2014) \\
\hline AZA2 & LD $_{50}$ & 875 & (Marine-Institute, 2014) \\
\hline AZA3 & LD & & \\
\hline
\end{tabular}

\section{In vitro toxicity}

\begin{tabular}{|l|l|l|l|l|l|}
\hline & \multicolumn{5}{|c|}{ Cell type } \\
\hline Compound & Jurkat T & HEK & 2-3 Days in & Neocortical & Neocortical \\
& (cytotoxicity) & 293 & vitro mice & neurons & neurons \\
& & (hERK & neurons & (LDH & (calcium \\
& & current) & (cytotoxicity) & release) & oscillations) \\
\hline AZA1 & 1 & 1 & 1 & 1 & 1 \\
\hline
\end{tabular}


ACCEPTED MANUSCRIPT

\begin{tabular}{|c|c|c|c|c|c|}
\hline AZA2 & 8.3 & 1.2 & 1.89 & 0.89 & 1.36 \\
\hline AZA3 & 4.5 & 1 & & 4.32 & 3.22 \\
\hline AZA4 & 0.6 & & & & \\
\hline AZA5 & 0.4 & & & & \\
\hline AZA6 & 7 & & & & \\
\hline AZA8 & 4.5 & & & & \\
\hline AZA9 & 0.4 & & & & -1 \\
\hline AZA10 & 0.2 & & & & \\
\hline AZA33 & 0.22 & & & & \\
\hline AZA34 & 5.5 & & & & \\
\hline $\begin{array}{l}\text { 37-epi- } \\
\text { AZA1 }\end{array}$ & 5.1 & & & & \\
\hline
\end{tabular}


Table 6. TEFs recommended by the Expert Group for each biotoxin group

\section{Saxitoxin group}

\begin{tabular}{|c|c|c|c|c|c|c|c|}
\hline Compound & $\begin{array}{l}\text { Oshima } \\
\text { Relative } \\
\text { Toxicity } \\
\text { values } \\
(\mathrm{MU} / \mu \mathrm{mole})\end{array}$ & $\begin{array}{l}\text { Mouse } \\
\text { LD }_{50} \\
\text { (i.p.) }\end{array}$ & $\begin{array}{l}\text { TEF based } \\
\text { on LD } 50 \text { by } \\
\text { gavage }\end{array}$ & $\begin{array}{l}\text { TEF based on } \\
\text { LD } 50 \text { by } \\
\text { voluntary } \\
\text { consumption }\end{array}$ & $\begin{array}{l}\text { EFSA } \\
\text { proposed } \\
\text { TEF }\end{array}$ & $\begin{array}{l}\text { Recommended } \\
\text { TEF }\end{array}$ & Rationale \\
\hline Saxitoxin & 1 & 1.00 & 1.00 & 1.00 & 1.0 & 1.0 & \\
\hline NeoSTX & 0.92 & 3.12 & 1.70 & 2.54 & 1.0 & 2.0 & $\begin{array}{l}\text { Oral studies show more potency than } \\
\text { STX. A value of } 2.0 \text { is recommended, } \\
\text { and supported by Na channel in vitro } \\
\text { results. }\end{array}$ \\
\hline GTX1 & 0.99 & & 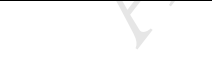 & & 1.0 & 1.0 & No new data \\
\hline
\end{tabular}




\begin{tabular}{|c|c|c|c|c|c|c|c|}
\hline GTX2 & 0.36 & & & & 0.4 & 0.4 & No new data \\
\hline GTX3 & 0.64 & & & & 0.6 & 0.6 & No new data \\
\hline GTX4 & 0.73 & & & & 0.7 & 0.7 & No new data \\
\hline GTX5 & 0.064 & 0.222 & 0.063 & 0.050 & 0.1 & 0.1 & $\begin{array}{l}\text { Oral } \mathrm{LD}_{50} \text { data suggest a lower TEF than i.p. } \\
\mathrm{LD}_{50} \text {. As for NeoSTX, in vitro Na channel } \\
\text { assays also support a TEF of } 0.1 \text {. }\end{array}$ \\
\hline GTX6 & & 0.122 & 0.038 & & 0.1 & 0.05 & New oral data show lower than 0.1 . \\
\hline $\mathrm{C} 1$ & 0.006 & & & & & 0.01 & $\begin{array}{l}\text { No new data } \\
\text { (rounded up: increments of } 0.05 \text { for } \\
\text { TEF }<0.1 \text { ) }\end{array}$ \\
\hline $\mathrm{C} 2$ & 0.096 & & & & 0.1 & 0.1 & No new data \\
\hline $\mathrm{C} 3$ & 0.013 & & & & & 0.01 & No new data \\
\hline $\mathrm{C} 4$ & 0.058 & & & & 0.1 & 0.1 & No new data \\
\hline
\end{tabular}




\begin{tabular}{|l|l|l|l|l|l|l|l|}
\hline dcSTX & 0.51 & 0.785 & 0.457 & 0.368 & 1.0 & $\mathbf{0 . 5}$ & New oral data (and supported by i.p. \\
& & & & & & & \\
toxicity data)
\end{tabular}

In case of saxitoxin analogues, for which no oral toxicity data were available, TEFs recommended are based on i.p.data

\section{Okadaic acid group}

\begin{tabular}{|l|l|l|l|l|l|l|}
\hline & TEF based & TEF based & TEF based on & EFSA & Recommended & Rationale \\
& on & on PP2A & membrane & proposed & TEF & \\
& cytotoxicity & inhibition & Paracellular & TEF & & \\
\hline OA & 1.0 & 1.0 & 1.0 & permeability & & \\
\hline
\end{tabular}




\begin{tabular}{|c|c|c|c|c|c|c|}
\hline DTX1 & 3.1 & 1.6 & $2-15$ & 1.0 & 1.0 & $\begin{array}{l}\text { There are several analogue specific reports from } \\
\text { human intoxications. Human intoxications in Japan } \\
\text { suggest a LOAEL of } 48 \mu \mathrm{g} \text { DTX1 per person, equivalent } \\
\text { to events of } 50 \mu \mathrm{g} \text { OA per person in Sweden, Norway, } \\
\text { UK and Portugal (EFSA, 2008c). Current used TEF of } \\
1.0 \text { is protective for public health. However in vitro } \\
\text { studies suggest potency of DTX1 is higher than OA. } \\
\text { The uncertainties of these studies (5-fold difference } \\
\text { between cell lines) suggest a TEF of } 1.0 \text { for DTX1 } \\
\text { should be assumed until further data is available. }\end{array}$ \\
\hline DTX2 & 0.52 & 0.5 & 0.6 & & 0.5 & $\begin{array}{l}\text { Consistent among the different assays; based on acute } \\
\text { oral and i.p. toxicity in mice, DTX-2 is on average } 0.5 \\
\text { times as toxic as DTX1). This value is also supported } \\
\text { by the various in vitro data }\end{array}$ \\
\hline
\end{tabular}




\begin{tabular}{|l|l|l|l|l|l|l|}
\hline DTX3 & & & & & $\begin{array}{l}\text { The TEF of the hydrolysis product of A0, DTX1 or } \\
\text { DTX2 would apply. }\end{array}$ \\
\hline
\end{tabular}

Domoic Acid

\begin{tabular}{|l|l|l|}
\hline & EFSA proposed TEF & Recommended TEF \\
\hline Domoic Acid (two epimers) & - & 1.0 \\
\hline
\end{tabular}

Azaspiracids

\begin{tabular}{|c|c|c|c|c|c|}
\hline & $\begin{array}{l}\text { TEF based on i.p. } \\
\text { toxicity }\end{array}$ & $\begin{array}{l}\text { TEF based on oral } \\
\text { toxicity }\end{array}$ & EFSA proposed TEF & Recommended TEF & Rational \\
\hline AZA2 & 0.6 & 0.7 & 1.8 & 0.7 & $\begin{array}{l}\text { Based on recent oral data. (also } \\
\text { consistent with recent i.p. data) }\end{array}$ \\
\hline AZA3 & 0.45 & 0.51 & 1.4 & 0.5 & $\begin{array}{l}\text { Based on recent oral data. (also } \\
\text { consistent with recent i.p. data) }\end{array}$ \\
\hline AZA4 & & $y$ & - & & No data \\
\hline
\end{tabular}




\begin{tabular}{|l|l|l|l|l|l|}
\hline AZA5 & & & - & & No data \\
\hline AZA6 & 0.7 & & - & $\mathbf{0 . 7}$ & No oral, only i.p. data. \\
\hline
\end{tabular}


Figure 1. Scheme of decisions to define and apply a TEF.

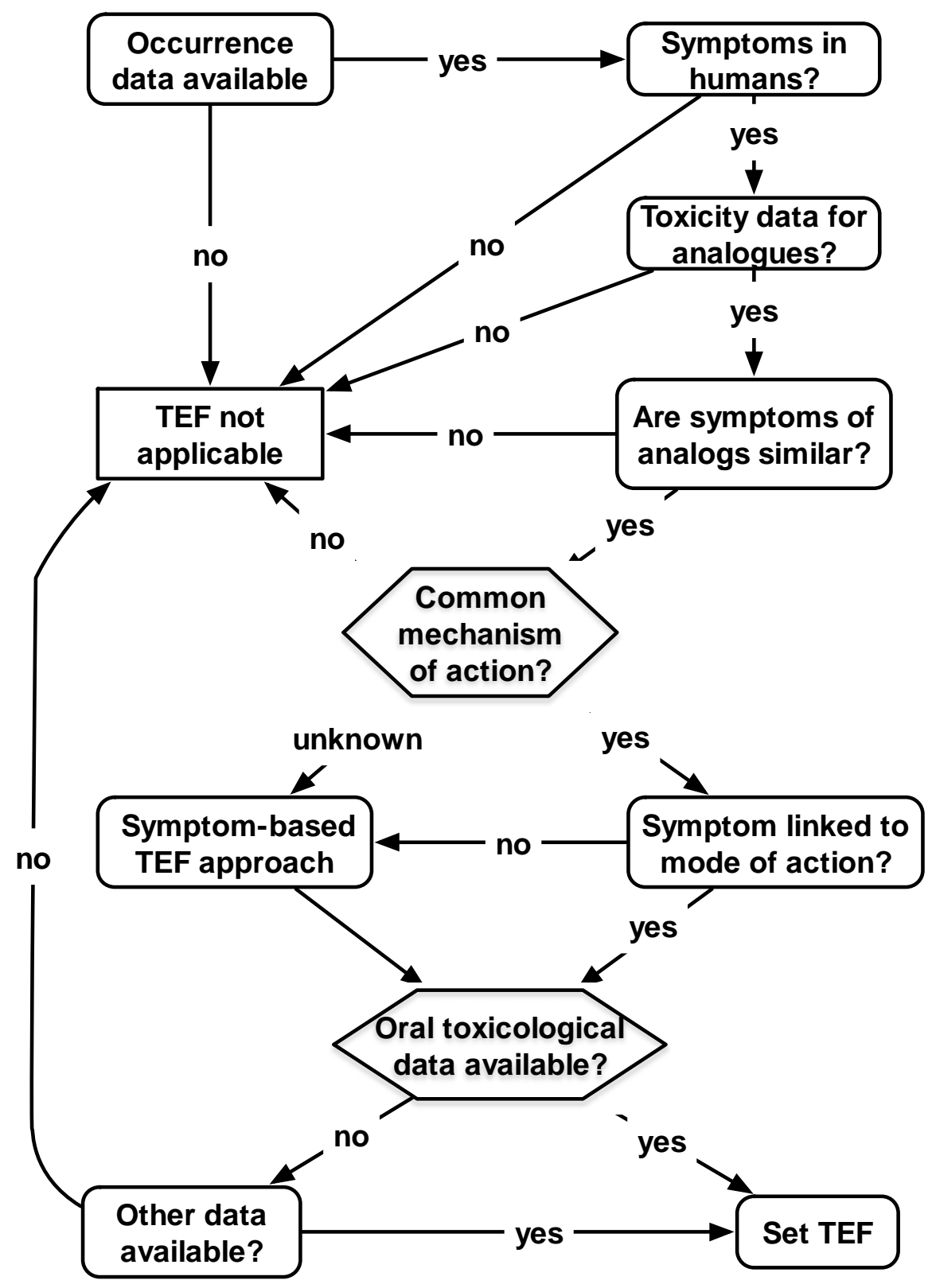




\section{References}

Abraham, W. M., Bourdelais, A. J., Sabater, J. R., Ahmed, A., Lee, T. A., Serebriakov, I., \& Baden, D. G. (2005). Airway responses to aerosolized brevetoxins in an animal model of asthma. Am J Respir Crit Care Med, 171, 26-34.

Alfonso, C., Rehmann, N., Hess, P., Alfonso, A., Wandscheer, C. B., Abuin, M., Vale, C., Otero, P., Vieytes, M. R., \& Botana, L. M. (2008). Evaluation of various $\mathrm{pH}$ and temperature conditions on the stability of azaspiracids and their importance in preparative isolation and toxicological studies. Anal Chem, 80, 9672-9680.

Alonso, E., Alfonso, A., Vieytes, M. R., \& Botana, L. M. (2016). Evaluation of toxicity equivalent factors of paralytic shellfish poisoning toxins in seven human sodium channels types by an automated high throughput electrophysiology system. Arch Toxicol, 90, 479-488.

Antelo, A., Alfonso, C., \& Alvarez, M. (2014). Standards for marine and freshwater toxins. In L. M. Botana (Ed.), Seafood and Freshwater Toxins: Pharmacology, Physiology and Detection (3rd ed., pp. 429-470). Boca Ratón: CRC Press.

AOAC. (2005a). AOAC Official Method 959.08 Paralytic Shellfish Poison. Biological Method. First Action 1959. Final Action. Official Methods of Analysis of the AOAC.

AOAC. (2005b). Domoic acid in mussels, liquid chromatographic method. Method 991.26. Official Methods of Analysis of the AOAC (Association of Official Analytical Chemists).

Atchison, W. D., Luke, V. S., Narahashi, T., \& Vogel, S. M. (1986). Nerve membrane sodium channels as the target site of brevetoxins at neuromuscular junctions. Br J Pharmacol, 89, 731-738.

Aune, T., Espenes, A., Aasen, J. A., Quilliam, M. A., Hess, P., \& Larsen, S. (2012). Study of possible combined toxic effects of azaspiracid- 1 and okadaic acid in mice via the oral route. Toxicon, 60, 895-906.

Aune, T., Larsen, S., Aasen, J. A., Rehmann, N., Satake, M., \& Hess, P. (2007). Relative toxicity of dinophysistoxin-2 (DTX-2) compared with okadaic acid, based on acute intraperitoneal toxicity in mice. Toxicon, 49, 1-7.

Baden, D. G., \& Mende, T. J. (1982). Toxicity of two toxins from the Florida red tide marine dinoflagellate, Ptychodiscus brevis. Toxicon, 20, 457-461.

Bane, V., Lehane, M., Dikshit, M., O'Riordan, A., \& Furey, A. (2014). Tetrodotoxin: chemistry, toxicity, source, distribution and detection. Toxins, 6, 693-755.

Bates, S. S., Bird, C. J., De Freitas, A. S. W., Foxall, R. A., Gilgan, M., Hanic, L. A., Johnson, G. R., McCulloch, A. W., Odense, P., Pocklington, R., Quilliam, M. A., Sim, P. G., Smith, J. C., Subba Rao, D. V., Todd, E. C. D., Walter, J. A., \& Wright, J. L. C. (1989). Pennate diatom Nitzschia pungens as the primary source of domoic acid, a toxin in shellfish from Eastern Prince Edward Island. Canada. Can. J. Fish. Aquat. Sci., 46, 1203-1215.

Bellocci, M., Sala, G. L., Callegari, F., \& Rossini, G. P. (2010). Azaspiracid-1 inhibits endocytosis of plasma membrane proteins in epithelial cells. Toxicological sciences, 117, 109-121.

Berman, F. W., \& Murray, T. F. (2000). Brevetoxin-induced autocrine excitotoxicity is associated with manifold routes of Ca2+ influx. $J$ Neurochem, 74, 1443-1451. 
Bialojan, C., \& Takai, A. (1988). Inhibitory effect of a marine-sponge toxin, okadaic acid, on protein phosphatases. Specificity and kinetics. Biochem J, 256, 283-290.

Botana, L. M., Alfonso, A., Vale, C., Vilariño, N., Rubiolo, J., Alonso, E., \& Cagide, E. (2014). The mechanistic complexities of phycotoxins: toxicology of azaspiracids and yessotoxins. In J. C. Fishbein \& J. M. Heiman (Eds.), Advances in Molecular Toxicology (First edition ed., Vol. 8, pp. 1-33). Oxford: Elsevier.

Botana, L. M., Vilariño, N., Elliott, C. T., Campbell, K., Alfonso, A., Vale, C., Louzao, M. C., \& Botana, A. M. (2010). The problem of toxicity equivalent factors in developping alternative methods to animal bioassays for marine toxin detection. Trends Anal. Chem., 29, 1316-1325.

Cao, Z., LePage, K. T., Frederick, M. O., Nicolaou, K. C., \& Murray, T. F. (2010). Involvement of caspase activation in azaspiracid-induced neurotoxicity in neocortical neurons. Toxicol Sci, 114, 323-334.

Chevallier, O. P., Graham, S. F., Alonso, E., Duffy, C., Silke, J., Campbell, K., Botana, L. M., \& Elliott, C. T. (2015). New insights into the causes of human illness due to consumption of azaspiracid contaminated shellfish. Sci Rep, 5, 9818.

Codex. (2008). Standard for live and raw bivalve molluscs. 292. In (pp. 1-7).

CODEX, A. (2006). Report of the Joint FAO/IOC/WHO ad hoc Expert Consultation on Biotoxins in Bivalve Molluscs; FAO/IOC/WHO 2004.

ftp://ftp.fao.org/es/esn/food/biotoxin report en.pdf. accessed July 11, 2016.

Crespo, A., Cifuentes, J. M., Bermúdez, R., Antelo, A., Alemañ, N., \& Botana, L. M. (2015). Dose-response and histopathological study, with special attention to the hypophysis, of the differential effects of domoic acid on rats and mice. Microsc Res Tech, 78, 396-403.

Dhar, B. C., Cimarelli, L., Singh, K. S., Brandi, L., Brandi, A., Puccinelli, C., Marcheggiani, S., \& Spurio, R. (2015). Molecular detection of a potentially toxic diatom species. Int J Environ Res Public Health, 12, 4921-4941.

Dickey, R. W., Bobzin, S. C., Faulkner, D. J., Bencsath, F. A., \& Andrzejewski, D. (1990). Identification of okadaic acid from a Caribbean dinoflagellate, Prorocentrum concavum. Toxicon, 28, 371-377.

Dominguez, H. J., Paz, B., Daranas, A. H., Norte, M., Franco, J. M., \& Fernandez, J. J. (2010). Dinoflagellate polyether within the yessotoxin, pectenotoxin and okadaic acid toxin groups: characterization, analysis and human health implications. Toxicon, 56, 191-217.

EFSA. (2008a). Marine biotoxin in shellfish-Azaspiracid group

Scientific Opinion of the Panel on Contaminants in the Food chain. In The EFSA Journal (Vol. 723, pp. 1-52).

EFSA. (2008b). Opinion of the Scientific Panel on Contaminants in the Food chain on a request from the European Commission on marine biotoxins in shellfish - azaspiracids. The EFSA Journal, 723, 1-52.

EFSA. (2008c). Opinion of the Scientific Panel on Contaminants in the Food chain on a request from the European Commission on marine biotoxins in shellfish - okadaic acid and analogues. The EFSA Journal, 589, 1-62. 
EFSA. (2009). Opinion of the Scientific Panel on Contaminants in the Food chain on a request from the European Commission on marine biotoxins in shellfish - Saxitoxin group. The EFSA Journal, 1019, 1-76.

Espina, B., Louzao, M. C., Cagide, E., Alfonso, A., Vieytes, M. R., Yasumoto, T., \& Botana, L. M. (2010). The methyl ester of okadaic acid is more potent than okadaic acid in disrupting the actin cytoskeleton and metabolism of primary cultured hepatocytes. Br J Pharmacol, 159, 337-344.

EU. (2011). Commission regulation (EU) No 15/2011 of 10 January 2011 amending Regulation (EC) No 2074/2005 as regards recognised testing methods for detecting marine biotoxins in live bivalve molluscs. Official Journal of the European Communities, L6, 3-4.

Ferreiro, S. F., Carrera, C., Vilarino, N., Louzao, M. C., Santamarina, G., Cantalapiedra, A. G., \& Botana, L. M. (2015). Acute cardiotoxicity evaluation of the marine biotoxins OA, DTX-1 and YTX. Toxins, 7, 10301047.

Ferreiro, S. F., Vilarino, N., Carrera, C., Louzao, M. C., Cantalapiedra, A. G., Santamarina, G., Cifuentes, J. M., Vieira, A. C., \& Botana, L. M. (2016a). Subacute Cardiotoxicity of Yessotoxin: In Vitro and in Vivo Studies. Chem Res Toxicol, 29, 981-990.

Ferreiro, S. F., Vilarino, N., Carrera, C., Louzao, M. C., Cantalapiedra, A. G., Santamarina, G., Cifuentes, J. M., Vieira, A. C., \& Botana, L. M. (2016b). Subacute Cardiovascular Toxicity of the Marine Phycotoxin Azaspiracid-1 in Rats. Toxicol Sci, 151, 104-114.

Ferreiro, S. F., Vilarino, N., Carrera, C., Louzao, M. C., Santamarina, G., Cantalapiedra, A. G., Rodriguez, L. P., Cifuentes, J. M., Vieira, A. C., Nicolaou, K. C., Frederick, M. O., \& Botana, L. M. (2014). In vivo arrhythmogenicity of the marine biotoxin azaspiracid-2 in rats. Arch Toxicol, 88, 425-434.

Ferron, P. J., Hogeveen, K., Fessard, V., \& Le Hegarat, L. (2014). Comparative analysis of the cytotoxic effects of okadaic acid-group toxins on human intestinal cell lines. Mar Drugs, 12, 4616-4634.

Gordon, C. J., Kimm-Brinson, K. L., Padnos, B., \& Ramsdell, J. S. (2001). Acute and delayed thermoregulatory response of mice exposed to brevetoxin. Toxicon, 39, 1367-1374.

Guo, X. T., Uehara, A., Ravindran, A., Bryant, S. H., Hall, S., \& Moczydlowski, E. (1987). Kinetic basis for insensitivity to tetrodotoxin and saxitoxin in sodium channels of canine heart and denervated rat skeletal muscle. Biochemistry, 26, 7546-7556.

Hallegraef, G. M. (2015). Harmful marine algal blooms and climate change: progress on a formidable predictive challenge. In L. M. Botana, M. C. Louzao \& N. Vilariño (Eds.), Climate change and marine and freshwater toxins (pp. 181-193). Berlin: De Gruyter.

Hartshorne, R. P., \& Catterall, W. A. (1981). Purification of the saxitoxin receptor of the sodium channel from rat brain. Proc Natl Acad Sci US A, 78, 46204624.

Hogberg, H. T., \& Bal-Price, A. K. (2011). Domoic Acid-Induced Neurotoxicity Is Mainly Mediated by the AMPA/KA Receptor: Comparison between Immature and Mature Primary Cultures of Neurons and Glial Cells from Rat Cerebellum. J Toxicol, 2011, 543512. 
Hu, T., Curtis, J. M., Walter, J. A., \& Wright, J. L. C. (1995). Identification of DTX-4, a new water-soluble DSP toxin derivatives from the dinoflagellate Prorocentrum lima. J. Chem. Soc. Chem. Comm., 1995, 597-599.

Hu, T., Doyle, J., Jackson, D., Marr, J., Nixon, E., Pleasance, S., Quilliam, M. A., Walter, J. A., \& Wright, J. L. C. (1992). Isolation of a new diarrhetic shellfish poison from Irish mussels. J. Chem. Soc. Chem. Comm., 39-41.

Hungerford, J. M. (1995). 35. Fish and other marine products. AOAC official method 959.08. Paralytic shellfish poison. Biological method. Final action. In P. Cunniff (Ed.), Official methods of analysis of AOAC International. (16th edition ed., Vol. 2, pp. 21-22). Arlington, VA: AOAC.

Ishida, H., Nozawa, A., Totoribe, K., Muramatsu, N., Nukaya, H., Tsuji, K., Yamaguchi, K., \& Yasumoto, T. (1995). Brevetoxin B1, a new polyether marine toxin from the New Zealand Shellfish Austrovenus stuchburyi. Tetrahedron Lett, 36, 725-728.

Ito, E. (2008). Toxicology of azaspiracid-1: acute and chronic poisoning, tumorigenicity, and chemical structure relationship to toxicity in a mouse model. In L. M. Botana (Ed.), Seafood and Freshwater toxins:

Pharmacology, Physiology and Detection (2nd edition ed., pp. 775-784). Boca Raton, FL: CRC Press (Taylor and Francis Group).

Ito, E., Satake, M., Ofuji, K., Higashi, M., Harigaya, K., McMahon, T., \& Yasumoto, T. (2002). Chronic effects in mice caused by oral administration of sublethal doses of azaspiracid, a new marine toxin isolated from mussels. Toxicon, 40, 193-203.

Ito, E., \& Terao, K. (1994). Injury and recovery process of intestine caused by okadaic acid and related compounds. Nat. Toxins, 2, 371-377.

Kao, C. Y. (1966). Tetrodotoxin, saxitoxin and their significance in the study of excitation phenomena. Pharmacol Rev, 18, 997-1049.

Kao, C. Y., Kao, P. N., James, K. M. R., Koehn, F. E., Wichmann, C. F., \& Schnoes, H. K. (1985). Actions of epimers of 12-(OH)-reduced saxitoxin and of 11(OSO3)-saxitoxin on squid axon. Toxicon, 23, 647-655.

Kao, C. Y., \& Walker, S. E. (1982). Active groups of saxitoxin and tetrodotoxin as deduced from actions of saxitoxin analogues on frog muscle and squid axon. J Physiol (Lond), 323, 619-637.

Kellmann, R., Schaffner, C. A., Gronset, T. A., Satake, M., Ziegler, M., \& Fladmark, K. E. (2009). Proteomic response of human neuroblastoma cells to azaspiracid-1.J Proteomics, 72, 695-707.

Klontz, K. C., Abraham, A., Plakas, S. M., \& Dickey, R. W. (2009). Mussel-associated azaspiracid intoxication in the United States. Ann Intern Med, 150, 361.

Kodama, M., \& Sato, S. (2008). Metabolism of paralytic shellfish toxins incorporated into bivalves. In L. M. Botana (Ed.), Seafood and Freshwater toxins: Pharmacology, Physiology and Detection (2nd edition ed., pp. 165175). Boca Raton, FL: CRC Press (Taylor and Francis Group).

Krock, B., Tillmann, U., Voss, D., Koch, B. P., Salas, R., Witt, M., Potvin, E., \& Jeong, H. J. (2012). New azaspiracids in Amphidomataceae (Dinophyceae). Toxicon, 60, 830-839.

Levin, E. D., Pizarro, K., Pang, W. G., Harrison, J., \& Ramsdell, J. S. (2005). Persisting behavioral consequences of prenatal domoic acid exposure in rats. Neurotoxicol Teratol, 27, 719-725. 
Llewellyn, L. E. (2006). The behavior of mixtures of paralytic shellfish toxins in competitive binding assays. Chem Res Toxicol, 19, 661-667.

Louzao, M. C., Fernandez, D. A., Abal, P., Fraga, M., Vilarino, N., Vieytes, M. R., \& Botana, L. M. (2015). Diarrhetic effect of okadaic acid could be related with its neuronal action: Changes in neuropeptide Y. Toxicol Lett, 237, 151-160.

Marine-Institute. (2014). Azaspiracids. Toxicological evaluation, test methods and identification of the source organisms (ASTOX II). Marine Research Sub-programme, (NDP 2007-13).

Marr, J. C., Hu, T., Pleasance, S., Quilliam, M. A., \& Wright, J. L. (1992). Detection of new 7-0-acyl derivatives of diarrhetic shellfish poisoning toxins by liquid chromatography-mass spectrometry. Toxicon, 30, 1621-1630.

McMahon, T. S., J. (1996). Winter toxicity of unknown aetiology in mussels. Harmful algae, 14, 2.

Moczydlowski, E., Hall, S., Garber, S. S., Strichartz, G. S., \& Miller, C. (1984). Voltage-dependent blockade of muscle $\mathrm{Na}+$ channels by guanidinium toxins. J Gen Physiol, 84, 687-704.

Moczydlowski, E. G. (2013). The molecular mystique of tetrodotoxin. Toxicon, 63, 165-183.

Morohashi, A., Satake, M., Naoki, H., Kaspar, H. F., Oshima, Y., \& Yasumoto, T. (1999). Brevetoxin B4 isolated from greenshell mussels Perna canaliculus, the major toxin involved in neurotoxic shellfish poisoning in New Zealand. Nat Toxins, 7, 45-48.

Munday, R. (2013). Is protein phosphatase inhibition responsible for the toxic effects of okadaic Acid in animals? Toxins, 5, 267-285.

Munday, R. (2014). Toxicology of seafood toxins: a critical review. In L. M. Botana (Ed.), Seafood and Freshwater Toxins: Pharmacology, Physiology and Detection (3rd ed., pp. 197-290). Boca Ratón: CRC Press.

Munday, R., Thomas, K., Gibbs, R., Murphy, C., \& Quilliam, M. A. (2013). Acute toxicities of saxitoxin, neosaxitoxin, decarbamoyl saxitoxin and gonyautoxins $1 \& 4$ and $2 \& 3$ to mice by various routes of administration. Toxicon, 76, 77-83.

Murata, M., Shimatani, M., Sugitani, H., Oshima, Y., \& Yasumoto, T. (1982). Isolation and structural elucidation of the causative toxin of the diarrhetic shellfish poisoning. Bull. Jpn. Soc. Sci. Fish., 48, 549-552.

Noguchi, T., Onuki, K., \& Arakawa, O. (2011). Tetrodotoxin poisoning due to pufferfish and gastropods, and their intoxication mechanism. ISRN Toxicol, 2011, 276939.

Ogino, H., Kumagai, M., \& Yasumoto, T. (1997). Toxicologic evaluation of yessotoxin. Nat. Toxins, 5, 255-259.

Oshima, Y. (1995). Postcolumn derivatization liquid chromatographic method for paralytic shellfish toxins. J. AOAC Int., 78, 528-532.

Payandeh, J., Scheuer, T., Zheng, N., \& Catterall, W. A. (2011). The crystal structure of a voltage-gated sodium channel. Nature, 475, 353-358.

Perez, S., Vale, C., Botana, A. M., Alonso, E., Vieytes, M. R., \& Botana, L. M. (2011). Determination of toxicity equivalent factors for paralytic shellfish toxins by electrophysiological measurements in cultured neurons. Chem Res Toxicol, 24, 1153-1157. 
Poli, M. A., Mende, T. J., \& Baden, D. G. (1986). Brevetoxins, unique activators of voltage-sensitive sodium channels, bind to specific sites in rat brain synaptosomes. Mol Pharmacol, 30, 129-135.

Rodriguez, P., Alfonso, A., Vale, C., Alfonso, C., Vale, P., Tellez, A., \& Botana, L. M. (2008). First toxicity report of tetrodotoxin and 5,6,11-trideoxyTTX in the trumpet shell Charonia lampas lampas in Europe. Anal Chem, 80, 56225629.

Roman, Y., Alfonso, A., Louzao, M. C., de la Rosa, L. A., Leira, F., Vieites, J. M., Vieytes, M. R., Ofuji, K., Satake, M., Yasumoto, T., \& Botana, L. M. (2002). Azaspiracid-1, a potent, nonapoptotic new phycotoxin with several cell targets. Cell Signal, 14, 703-716.

Sala, G. L., Bellocci, M., Callegari, F., \& Rossini, G. P. (2013). Azaspiracid-1 inhibits the maturation of cathepsin D in mammalian cells. Chem Res Toxicol, 26, 444-455.

Satake, M., Ofuji, K., James, K. J., Furey, A., \& Yasumoto, T. (1998). New toxic event caused by Irish mussels. In B. Reguera, J. Blanco \& M. L. Fernandez (Eds.), Harmful Algae, Proceedings of the VIII International Conference on Harmful Algae, June 1999, Vigo, Spain. (pp. 468-469). Santiago de Compostela: Xunta de Galicia and Intergovernmental Oceanographic Commission of UNESCO.

Satake, M., Ofuji, K., Naoki, H., James, K. J., Furey, A., McMahon, T., Silke, J., \& Yasumoto, T. (1998). Azaspiracid, a New Marine Toxin Having Unique Spiro Ring Assemblies, Isolated from Irish Mussels, Mytilus edulis. J. Am. Chem. Soc., 120, 9967-9968.

Schantz, E. J., McFarren, E. F., Schafer, M. L., \& Lewis, K. H. (1958). Purified shellfish poison for bioassay standardization.J Assoc Off Anal Chem, 41.

Shimizu, Y., Chou, H. N., Bando, H., Van Duyne, G., \& Clardy, J. (1986). Structure of brevetoxin A (GB-1 toxin), the most potent toxin in the Florida red tide organism Gymnodinium breve (Ptychodiscus brevis). J Am Chem Soc, 108, 514-515.

Silva, M., Azevedo, J., Rodriguez, P., Alfonso, A., Botana, L. M., \& Vasconcelos, V. (2012). New gastropod vectors and tetrodotoxin potential expansion in temperate waters of the Atlantic Ocean. Mar Drugs, 10, 712-726.

Solino, L., Sureda, F. X., \& Diogene, J. (2015). Evaluation of okadaic acid, dinophysistoxin-1 and dinophysistoxin-2 toxicity on Neuro-2a, NG108-15 and MCF-7 cell lines. Toxicol In Vitro, 29, 59-62.

Sommer, H., \& Meyer, K. F. (1937). Paralytic shellfish poisoning. Arch. Path., 24, 560-598.

Strichartz, G. (1984). Structural determinants of the affinity of saxitoxin for neuronal sodium channels. Electrophysiological studies on frog peripheral nerve. J Gen Physiol, 84, 281-305.

Suzuki, H. (2012). Susceptibility of different mice strains to okadaic acid, a diarrhetic shellfish poisoning toxin. Food Addit Contam Part A Chem Anal Control Expo Risk Assess, 29, 1307-1310.

Suzuki, H., \& Machii, K. (2014). Comparison of toxicity between saxitoxin and decarbamoyl saxitoxin in the mouse bioassay for paralytic shellfish poisoning toxins. J Vet Med Sci, 76, 1523-1525.

Tachibana, K., Scheuer, P. J., Tsukitani, H., Van Engen, D., Clardy, J., Gopichand, Y., \& Schmitz, F. J. (1981). Okadaic acid, a cytotoxic polyether from two 
marine sponges of the genus a Halichondria. J. Am. Chem. Soc., 103, 24692471.

Takai, A., Bialojan, C., Troschka, M., \& Ruegg, J. C. (1987). Smooth muscle myosin phosphatase inhibition and force enhancement by black sponge toxin. FEBS Lett, 217, 81-84.

Takemoto, T., \& Daigo, K. (1958). Constituents of Chondria armata. Chem Pharmaceutical Bull., 6, 578-580.

Templeton, C. B., Poli, M. A., \& LeClaire, R. D. (1989). Cardiorespiratory effects of brevetoxin (PbTx-2) in conscious, tethered rats. Toxicon, 27, 1043-1049.

Terao, K., Ito, E., Ohkusu, M., \& Yasumoto, T. (1993). A comparative study of the effects of DSP-toxins on mice and rats. In T. J. Smayda \& Y. Shimizu (Eds.), Toxic phytoplankton blooms in the sea. (pp. 581-586). New York: Elsevier Sci. Publishers B.V.

These, A., Klemm, C., Nausch, I., \& Uhlig, S. (2011). Results of a European interlaboratory method validation study for the quantitative determination of lipophilic marine biotoxins in raw and cooked shellfish based on high-performance liquid chromatography-tandem mass spectrometry. Part I: collaborative study. Anal Bioanal Chem, 399, 12451256.

Tillmann, U., Salas, R., Jauffrais, T., Hess, P., \& Silke, J. (2014). AZA: The producing organisms-Biology and trophic transfer. In L. M. Botana (Ed.), Seafood and Freshwater Toxins: Pharmacology, Physiology and Detection (3rd ed., pp. 773-795). Boca Ratón: CRC Press.

Trainer, V. L., Moreau, E., Guedin, D., Baden, D. G., \& Catterall, W. A. (1993). Neurotoxin binding and allosteric modulation at receptor sites 2 and 5 on purified and reconstituted rat brain sodium channels. J Biol Chem, 268, 17114-17119.

Tripuraneni, J., Koutsouris, A., Pestic, L., De Lanerolle, P., \& Hecht, G. (1997). The toxin of diarrheic shellfish poisoning, okadaic acid, increases intestinal epithelial paracellular permeability. Gastroenterology, 112, 100-108.

Truelove, J., Mueller, R., Pulido, O., \& Iverson, F. (1996). Subchronic toxicity study of domoic acid in the rat. Food Chem Toxicol, 34, 525-529.

Tubaro, A., Sosa, S., Bornacin, A., \& Jungerford, J. (2008). Pharmacology and toxicology of diarrheic shellifsh toxins. In L. M. Botana (Ed.), Seafood and Freshwater toxins: Pharmacology, Physiology and Detection (2nd edition ed., pp. 229-253). Boca Raton, FL: CRC Press (Taylor and Francys Group).

Tubaro, A., Sosa, S., Carbonatto, M., Altinier, G., Vita, F., Melato, M., Satake, M., \& Yasumoto, T. (2003). Oral and intraperitoneal acute toxicity studies of yessotoxin and homoyessotoxins in mice. Toxicon, 41, 783-792.

Turner, A., Powell, A., Schofield, A., Lees, D., \& Baker-Austin, C. (2015). Detection of the pufferfish toxin tetrodotoxin in European bivalves, England, 2013 to 2014. Euro surveillance : bulletin europeen sur les maladies transmissibles = European communicable disease bulletin, 20.

Turner, A. D., McNabb, P. S., Harwood, D. T., Selwood, A. I., \& Boundy, M. J. (2015). Single-Laboratory Validation of a Multitoxin Ultra-Performance LCHydrophilic Interaction LC-MS/MS Method for Quantitation of Paralytic Shellfish Toxins in Bivalve Shellfish. J AOAC Int, 98, 609-621. 
Twiner, M., Doucette, G. J., Rasky, A., Huang, X. P., Roth, B. L., \& Sanguinetti, M. C. (2012). Marine algal toxin azaspiracid is an open-state blocker of hERG potassium channels. Chem Res Toxicol, 25, 1975-1984.

Twiner, M., Hanagriff, J. C., Butler, S., Madhkoor, A. K., \& Doucette, G. J. (2012). Induction of apoptosis pathways in several cell lines following exposure to the marine algal toxin azaspiracid. Chem Res Toxicol, 25, 1493-1501.

Twiner, M., Hess, P., Bottein, M. Y., McMahon, T., Samons, M. S., Satake, M., Yasumoto, T., Ramsdell, J. S., \& Doucette, G. J. (2005). Cytotoxic and cytoskeletal effects of azaspiracid-1 on mammalian cell lines. Toxicon, 45, 891-900.

Twiner, M., Hess, P., \& Doucette, G. J. (2014). Azaspiracids: toxicology, pharmacology and risk assessment. In L. M. Botana (Ed.), Seafood and Freshwater Toxins: Pharmacology, Physiology and Detection (3rd ed., pp. 824-855). Boca Ratón: CRC Press.

Twiner, M., Ryan, J., Morey, J., Smith, K., Hammad, S., Van Dolah, F., Hess, P., McMahon, T., Satake, M., Yasumoto, T., \& Doucette, G. (2008). Transcriptional profiling and inhibition of cholesterol biosynthesis in human T lymphocyte cells by the marine toxin azaspiracid. Genomics, 91, 289-300.

Usup, G., Leaw, C. P., Cheah, M. Y., Ahmad, A., \& Ng, B. K. (2004). Analysis of paralytic shellfish poisoning toxin congeners by a sodium channel receptor binding assay. Toxicon, 44, 37-43.

Vale, C., Alfonso, A., Vieytes, M. R., Romaris, X. M., Arevalo, F., Botana, A. M., \& Botana, L. M. (2008). In vitro and in vivo evaluation of paralytic shellfish poisoning toxin potency and the influence of the $\mathrm{pH}$ of extraction. Anal Chem, 80, 1770-1776.

Vale, C., Nicolaou, K. C., Frederick, M. O., Vieytes, M. R., \& Botana, L. M. (2010). Cell volume decrease as a link between azaspiracid-induced cytotoxicity and c-Jun-N-terminal kinase activation in cultured neurons. Toxicol Sci, 113, 158-168.

Vale, C., Wandscheer, C., Nicolaou, K. C., Frederick, M. O., Alfonso, C., Vieytes, M. R., \& Botana, L. M. (2008). Cytotoxic effect of azaspiracid-2 and azaspiracid-2-methyl ester in cultured neurons: involvement of the c-Jun N-terminal kinase. J Neurosci Res, 86, 2952-2962.

Van den Berg, M., Birnbaum, L. S., Denison, M., De Vito, M., Farland, W., Feeley, M., Fiedler, H., Hakansson, H., Hanberg, A., Haws, L., Rose, M., Safe, S., Schrenk, D., Tohyama, C., Tritscher, A., Tuomisto, J., Tysklind, M., Walker, N., \& Peterson, R. E. (2006). The 2005 World Health Organization reevaluation of human and Mammalian toxic equivalency factors for dioxins and dioxin-like compounds. Toxicol Sci, 93, 223-241.

Vieira, A. C., Aleman, N., Cifuentes, J. M., Bermudez, R., Pena, M. L., \& Botana, L. M. (2015). Brain Pathology in Adult Rats Treated With Domoic Acid. Vet Pathol, 52, 1077-1086.

Vieira, A. C., Cifuentes, J. M., Bermudez, R., Ferreiro, S. F., Castro, A. R., \& Botana, L. M. (2016). Heart Alterations after Domoic Acid Administration in Rats. Toxins, 8, 68; doi:10.3390/toxins8030068.

Vieira, A. C., Rubiolo, J. A., Lopez-Alonso, H., Cifuentes, J. M., Alfonso, A., Bermudez, R., Otero, P., Vieytes, M. R., Vega, F. V., \& Botana, L. M. (2013). Oral toxicity of okadaic acid in mice: study of lethality, organ damage, 
distribution and effects on detoxifying gene expression. Toxins, 5, 20932108.

Vilarino, N., Nicolaou, K. C., Frederick, M. O., Vieytes, M. R., \& Botana, L. M. (2007). Irreversible cytoskeletal disarrangement is independent of caspase activation during in vitro azaspiracid toxicity in human neuroblastoma cells. Biochem Pharmacol, 74, 327-335.

Vlamis, A., Katikou, P., Rodriguez, I., Rey, V., Alfonso, A., Papazachariou, A., Zacharaki, T., Botana, A. M., \& Botana, L. M. (2015). First Detection of Tetrodotoxin in Greek Shellfish by UPLC-MS/MS Potentially Linked to the Presence of the Dinoflagellate Prorocentrum minimum. Toxins, 7, 17791807.

Vranyac-Tramoundanas, A., Harrison, J. C., Sawant, P. M., Kerr, D. S., \& Sammut, I. A. (2011). Ischemic cardiomyopathy following seizure induction by domoic Acid. Am J Pathol, 179, 141-154.

Walker, J. R., Novick, P. A., Parsons, W. H., McGregor, M., Zablocki, J., Pande, V. S., \& Du Bois, J. (2012). Marked difference in saxitoxin and tetrodotoxin affinity for the human nociceptive voltage-gated sodium channel (Nav1.7) [corrected]. Proc Natl Acad Sci U S A, 109, 18102-18107.

Wang, J., Wang, Y. Y., Lin, L., Gao, Y., Hong, H. S., \& Wang, D. Z. (2012). Quantitative proteomic analysis of okadaic acid treated mouse small intestines reveals differentially expressed proteins involved in diarrhetic shellfish poisoning. J Proteomics, 75, 2038-2052.

Watanabe, R., Suzuki, T., \& Oshima, Y. (2010). Development of quantitative NMR method with internal standard for the standard solutions of paralytic shellfish toxins and characterisation of gonyautoxin- 5 and gonyautoxin- 6 . Toxicon, 56, 589-595.

Wiese, M., D'Agostino, P. M., Mihali, T. K., Moffitt, M. C., \& Neilan, B. A. (2010). Neurotoxic alkaloids: saxitoxin and its analogs. Mar Drugs, 8, 2185-2211.

Wingerd, J. S., Vetter, I., \& Lewis, R. J. (2012). Voltage-gated sodium channels as therapeutic targets. In L. M. Botana \& M. I. Loza (Eds.), Therapeutic targets. Modulation, inhibition and activation. (pp. 63-122). Hoboken, NJ: John Wiley \& Sons.

Yang, L., Kao, C. Y., \& Oshima, Y. (1992). Actions of decarbamoyloxysaxitoxin and decarbamoylneosaxitoxin on the frog skeletal muscle fiber. Toxicon, 30, 645-652.

Yasumoto, T., \& Murata, M. (1990). Polyether toxin involved in seafood poisoning. In S. Hall \& G. Stritchartz (Eds.), Marine toxins (pp. 120-132). Washington D.C.: American Chemical Society.

Yasumoto, T., Murata, M., Oshima, Y., Matsumoto, G. K., \& Glardy, J. (1984). Diarrhetic shellfish poisoning. In E. P. Ragelis (Ed.), ACS Symp. Series. No 262. Seafood toxins. (pp. 207-214). Washington, D.C.: American Chemical Society.

Yasumoto, T., Murata, M., Oshima, Y., \& Sano, M. (1985). Diarrhetic Shellfish Toxins. Tetrahedron, 41, 1019-1025.

Yasumoto, T., Oshima, Y., \& Yamaguchi, M. (1978a). Occurrence of a new type of toxic shellfish in Japan and chemical properties of the toxin. In D. L. Taylor \& H. H. Seliger (Eds.), Dinoflagellate Blooms (pp. 1249-1255). Amsterdam: Elsevier/North Holland. 
Yasumoto, T., Oshima, Y., \& Yamaguchi, M. (1978b). Ocurrence of a new type of shellfish poisoning in the Tohoku Distric. Bull. Jpn. Soc. Sci. Fish., 44, 12491255.

Yasumoto, T., Yotsu-Yamashita, M., Murata, M., \& Naoki, H. (1988). New tetrodotoxin analogues from the newt Cynops ensicaudata. J. Am. Chem. Soc., 110. 